\title{
ÉPICA, MEMORIA E HISTORIA cómo los CARolingIOS escriben el MUNdo ${ }^{1}$
}

\author{
Gerardo Rodríguez \\ gerodri@sinectis.com.ar
}

Resúmen: En las obras de los historiadores carolingios de la novena centuria, Luis aparece no solo como el sucesor de Carlomagno sino, en especial, como un monarca que aspira a la continuidad de la Renovatio Regni Francorum. Es por ello que nada de lo que dicen estos autores es dicho al azar sino que son expresiones de un verdadero proyecto ideológico, cultural y político, de allí que considere a dichas obras como "objetos construidos", que sirven no solo para interpretar una realidad sino también para crearla. La construcción de una tradición franco-carolingia, a partir del análisis de las relaciones entre literatura e historia, remite al análisis del discurso, análisis que no puede entenderse como el estudio de una fórmula pura y perfecta sino que debe considerar los encuadres de producción, recepción, contenido, tiempo y espacio que le sirven de marco de referencia, en este caso, la producción histórica y literaria de la "renovación cultural carolingia", caracterizada por los fuertes lazos que vinculan la épica y la teología con la historia.

Palabras-Claves: Francos, Carolingios, Luis el Piadoso.

La historia política de la Alta Edad Media ha merecido importantes estudios desde mediados del siglo XIX y hasta la actualidad, estudios que han puesto de manifiesto la estrecha relación entre la historia, las ciencias sociales y humanas y el contexto social e intelectual de cada época. Es por ello, que la visión de los siglos VI al X se ha ido modificando con el transcurrir del tiempo y de la historiografía.

Entre fines del siglo XIX y principios del siglo XX, la historia política se asociaba a las instituciones y al ordenamiento jurídico-político de Europa. En especial, tres historiadores han dado cuenta del proceso de construcción

* Doctor en Historia, docente e investigador en la Facultad de Humanidades de la Universidad Nacional de Mar del Plata y en el Departamento de Humanidades de la Universidad Nacional del Sur, director del Centro de Estudios e Investigaciones de las Culturas Antigua y Medieval de la Universidad Nacional del Sur. 
del estado-nación y del desarrollo de burocracias estatales, particularmente en la novena centuria: Georg Waitz (1844), Numa Denis Fustel de Coulanges (1908) y Frederic William Maitland (1907; 1911). Estos historiadores prestaron especial atención a la herencia del Imperio romano al caracterizar las organizaciones estatales del período y la verticalidad de las sociedades que las sustentaban.

Estas ideas fueron desarrolladas y aplicadas para el caso franco, especialmente carolingio, por François-Louis Ganshof (1971; 1968), quien se convirtió en un referente historiográfico de la llamada "escuela institucional". Según esta vertiente, la unidad política carolingia resultó efímera, dado que el gobierno del Imperio se sostenía sobre bases endebles, como lo eran la itinerancia del rey y la delegación del poder real en instituciones administrativas que resultaron ineficientes.

Sin embargo, desde mediados de los años sesenta del siglo XX, estas miradas comenzaron a modificarse, dando lugar a estudios que subrayaron sus características propias y específicas, ${ }^{2}$ más allá de la innegable herencia romana, que se vincularon con las construcciones nacionales, estatales de los siglos VII y VIII y con los debates en torno a la etnicidad y las identidades nacionales. ${ }^{3}$

A partir de esta renovación, otros temas surgieron como relevantes, en particular los que vincularon historia política y poder, tales como rituales, simbolismo y relaciones entre estructuras sociales y regímenes políticos. ${ }^{4}$

En los años ochenta, la historia cultural y el giro antropológico tuvieron un fuerte impacto en los estudios referidos al mundo medieval en general, carolingio en particular, dando lugar a una vigorosa tradición historiográfica que se mantiene hasta la actualidad. ${ }^{5}$

Estas miradas culturales y políticas pusieron el acento en la documentación de tipo narrativo, (GOFFART, 2005; MCKITTERICK, 1990; MCKITTERICK, 2004; TYLER, BALZARETTI, 2006) en el estudio de la poesía carolingia, (GODMAN, 1987) en la ampliación de las fuentes (numismática, epigrafía, heráldica), (TREFFORT, 2007; GARIPZANOV, 2008) en la renovada interpretación de los textos exegéticos, (HERNÁNDEZ, 2010) en las nuevas estructuras sociales, (FICHTENAU, 1991; LE JAN, 1998; DEPREUX, 2002) en las relaciones entre cultura y poder (RODRÍGUEZ DE LA PEÑA, 2008) y en la dispersión del poder en diversas áreas de Europa Occidental (DAVIES, FOURACRE, 1986; INNES, 2000; JONG, THEUWS, VAN RHIJN, 2001; HUMMER, 2006).

Los resultados de estas investigaciones y propuestas teóricas permitieron dejar atrás tópicos tales como "la debilidad del Imperio carolingio" 
o bien "los límites reales de un Imperio ideal" para plantear hipótesis que consideraban los fuertes regionalismos presentes en el Imperio o las tensiones entre centro y periferias, nunca resueltas ni aún en tiempos de Carlomagno. ${ }^{6}$

Desde esta perspectiva, Janet Nelson $(2005 ; 2006)$ habla de "pequeños mundos", de poderes locales, expresiones que utiliza para confrontar la idea de una unidad política carolingia extendida en el tiempo y en el espacio. Estas miradas consideran que el Imperio carolingio es el resultado de las relaciones y tensiones entre los distintos poderes regionales con los monarcas de la dinastía. Asistimos hoy a una nueva idea de Imperio carolingio, basada en la tensión entre lo universal y lo local y en la importancia del cristianismo en la construcción del Imperio. ${ }^{7}$

Julia Smith (2005, p. 6-7), al subrayar los aportes de la nueva historia cultural, pone énfasis en los estudios de discursos, lenguajes y literatura en general, e histórica en particular, que prestaron atención al impacto, a la importancia de los textos en la generación de las diferentes realidades del poder y permitieron ponderar y valorar una perspectiva microhistórica en un contexto más amplio, como lo es el pluralismo de la experiencia histórica. (SMITH, 2005, p.6-7) Este pluralismo de la experiencia histórica ha permitido que varios autores replantearan las relaciones exteriores del Imperio carolingio, es decir, en el contexto de los Imperios (SYPECK, 2006) o de los procesos históricos principales (NOBLE, 2009) de los siglos VIII a X.

Para reconstruir gran parte de estas temáticas, los historiadores recurren a documentación de tipo histórico-narrativa. Joaquín Martínez Pizarro subraya la importancia de esta "literatura narrativa", a pesar de que las apreciaciones históricas que contiene resultan ser muchas veces subjetivas y parciales y de la "evidencia narrativa" que contienen, pues se incluyen referencias astronómicos precisas, características de las construcciones edilicias, datos referidos al ordenamiento jurídico, entre otros.

En esta literatura se encuentran, también, estereotipos retóricos que continuamente son adaptados, elaborados, transformados dando lugar a una verdadera operación de manipulación del pasado, que fija una serie de tópoi que resultan familiares, que se retoman y recargan ideológicamente (MARTÍNEZ PIZARRO, 1989; COUMERT, 2007).

Sin dudas, cada época histórica genera un nuevo modelo, una nueva forma de relación presente - pasado, que pone en evidencia cómo se conjugan emulación e innovación (NELSON, 1994, p. 72; MCKITTERICK, p. 207-209). En los casos de Ermoldo (1964), Astrónomo (1995) y Thegan (1995), este nuevo modelo sostiene y difunde una "liturgia de la autoridad" que, aunque con matices y variantes, permite aunar la tradición franca del Rex francorum 
con la romana de imperator Augustus, la cristiana de imperium Christianum y la novedad altomedieval de gratia Dei rex (GARIPZANOV, 2008, p. 1-41). .Así, por ejemplo, en el aula regia del palacio imperial de Ingelheim hay una puesta en escena de esta ligazón, dado que Luis es presentado como emperador romano-cristiano, dominador de los paganos y rodeado de frescos en los que están presentes Constantino, Teodosio, Carlos Martel, Pipino el Breve y Carlomagno. ${ }^{8}$

En las obras de los historiadores carolingios de la novena centuria, Luis aparece no solo como el sucesor de Carlomagno sino, en especial, como un monarca que aspira a la continuidad de la Renovatio Regni Francorum (SEMMLER, 1990, p. 125-146). Nada de lo que dicen, pues, es dicho al azar sino que son expresiones de un verdadero proyecto ideológico, cultural y político, de allí que considere a dichas obras como "objetos construidos", (MORSEL, 2004, p. 273-286) que sirven no solo para interpretar una realidad sino también para crearla. ${ }^{9}$

Se podría hablar de "objetos construidos narrativamente", de un pasado que toma cuerpo a partir de determinadas prácticas y estrategias discursivas. De allí los necesarios cuidados metodológicos que el historiador debe tener para enfrentar dichas fuentes. Philippe Depreux (2002) señala, en la misma línea que J. Martínez Pizarro, que la documentación narrativa del período carolingio contiene mucha información fidedigna (descripciones territoriales, arquitectónicas, referencias litúrgicas entre otras) junto a otra que se encuentra tergiversada en función de los intereses de los participantes. ${ }^{10}$

En esta última línea de análisis incluyo este trabajo así como mis estudios recientes sobre los historiadores carolingios del siglo IX, (RODRÍGUEZ, 2009, RODRÍGUEZ, 2011; RODRÍGUEZ in CATTEDRA, 2011; RODRÍGUEZ in RODRÍGUEZ, 2011) dado que me permite analizar la obra de los cuatro historiadores mencionados, reconociendo su importancia como testimonios históricos de la Alta Edad Media. ${ }^{11}$

Ahora bien, estas "narraciones históricas" de carácter nacional, en tanto preocupadas por un reinado, por la relación de una serie de acontecimientos en un contexto preciso y acotado espacial y temporalmente, por una sucesión determinada dentro del mundo franco, tienen una función social, ${ }^{12}$ dado que conforman una determinada visión del mundo, muchas veces asociada a uno de los bandos en pugna, en la cual enfatizan las cuestiones inherentes a la ligazón entre religión, política y sociedad.

Por ello, estos autores pueden ser considerados como verdaderos "intelectuales" al servicio de una causa, "intelectuales" que recurren al uso y la difusión de la escritura en su búsqueda por determinar criterios de 
verdad. ${ }^{13} \mathrm{Al}$ respecto, Chris Wickham (2009, p. 411) afirma que la relación entre "intelectuales" y política que se establece en el siglo noveno no se dará nuevamente hasta la revolución francesa. ${ }^{14}$ En este sentido, Matthias Becher (1993, p. 21-77) sostiene que los Anales carolingios pueden ser considerados como una versión semioficial de la historia, el basamento sobre el que se desarrollan las demás narrativas del período. Una idea similar es la propuesta por Rosamond McKitterick (2000, p. 1-20) quien habla de la ilusión del poder real que transmiten.

Como es posible observar, la palabra escrita cumplió una función de primer orden en la sociedad carolingia, dado que fue utilizada por el gobierno, por la administración, en las transacciones legales ordinarias y en las disposiciones en general. La palabra escrita permitió conformar una tradición histórica y cultural franca a partir de la reelaboración de las herencias romana, cristiana y germana. De allí que Rosamond McKitterick (1990, p. 134) afirme que "para los francos la memoria era el recuerdo escrito” (MCKITTERICK, 1989, p.134). ${ }^{15}$ Es por ello que la literatura adquiere relevancia, dado que la extensión y la importancia concedidas a la memoria constituye tareas reservadas para una élite (letrada). (MCKITTERICK, 2004, p.5-7; Cf. LE JAN, 1998; SCHMITT, 2005, p.31-52, en especial p.47-51)

La palabra escrita, esencial en la conformación de la cultura carolingia, encontró en la literatura un fértil campo de acción, en especial en los entrecruzamientos entre historia y literatura, entre historia y epopeya. ${ }^{16}$

A principios del siglo XX cobró fuerza el análisis de los lazos que unían o los límites que distinguían a la historia de la epopeya, a partir de la afirmación realizada por Ramón Menéndez Pidal referida a la emotividad del discurso épico, que idealiza el pasado y lo presenta de manera ordenada y poética (MENÉNDEZ PIDAL, CATALÁN, BUSTOS, 1992; MENÉNDEZ PİDAL, 1953). Por el contrario, las tradiciones francesa y anglosajona han subrayado las fuertes vinculaciones, temáticas y narrativas, entre la canción de gesta y la historia carolingia o capeta. En particular, sobresalen los estudios de Joseph Bédier (BÉDIER; 1914; LOT, 1939; CORBELLARI, 1988), Rita Lejeune (1935; 1948), J. Frappier (1957), Ferdinand Lot (1958; PERRIN, 1968), retomados en la actualidad por diversos autores, en particular Joseph Duggan (1986).

Según P. Geary (1994, p.7), esta escritura de la memoria permitirá tanto el control del pasado como su presencia en el presente. La creación del pasado permitirá el desarrollo de la "memoria colectiva", que se transmitirá tanto de manera oral como a través de la literatura. (GEARY, 1994, p.7) 
En los siglos octavo y noveno, la memoria oral y la memoria escrita disputan el tratamiento, la selección y la interpretación de la escritura. Incluso algunos autores sostienen que esa cultura oral era esencial, (CARRUTHERS, 1990 , p.11) ${ }^{17}$ otros, en cambio, consideran que la "memoria social", básicamente escrita, remitía al proceso de construcción y de reflexión del pasado (FENTRESS; WICKHAM, 1992, p. 26). ${ }^{18}$

Pero ¿qué sabemos de estos historiadores del siglo IX? ¿Es posible reconstruir sus trayectorias intelectuales y políticas? ¿Cómo elaboraban sus textos? ¿Quiénes los leían, escuchaban o copiaban? ¿Cómo era la recepción y circulación de los mismos?

Ermoldo Nigello concluye el panegírico In Honorem Hludowici Pii entre los años 826 y 828 - en todo caso es anterior a los sucesos de 829 que tanto influyen en la e scritura de Thegan y Astrónomo (FLEINER, 1996). Fue Ermoldo un historiador de amplia cultura, probablemente clérigo, que "transmite un mensaje espiritual", que "respira la ética del período en el que nace" ${ }^{19}$ y describe la identidad y la unidad del cuerpo socio-político a partir de preceptos religiosos. Sin embargo, su figura genera controversia, conocida como "la cuestión Ermoldo".

Para Donna Boutelle (1970, p. 176; 1971), Ermoldo es el primer biógrafo de la época carolingia, dado que la obra, escrita en 826 , fija las pautas que seguirán los poetas-historiadores de la novena centuria (Eginardo, Thegan, Astrónomo, Nitardo, Notker): se trata de un speculum regis, una apología del rey - emperador carolingio escrita para ganarse la anuencia de Luis, quien lo había castigado con el exilio en Santa María de Estrasburgo, por alguna indiscreción cortesana -en el mejor de los casos- o bien por un asesinato, del que participó en la década del veinte.

Ludovico Muratori, al editar su obra en el siglo XVIII, lo identificó con Ermenaldus, abad de Aniane, ${ }^{20}$ en tanto Ernst Dümmler (1881, p. 1-79) prefiere hacerlo con el canciller Hermoldus de la corte de Pipino (838) y Dom Bouquet (1737-1742, VI, p. 1-66) con el Hermoldus abad, presente en 834 en la corte de Pipino. Para Jean Tourneur-Aumont (1923, p. 449-475) se trata, en cambio, de Ermeno, conde de Poitiers.

Desde mediados del siglo XX, a partir de los trabajos de F. Ganshof (1957) en la década del cincuenta y de Thomas Noble $(1976,1980)$ en la década de los setenta, el reinado de Luis en su conjunto y la obra de Ermoldo han sido "reconsiderados". Ermoldo no es solamente un "hombre de letras" sino un verdadero historiador, a pesar de algunas limitaciones concretas que presenta: su lenguaje es impreciso, ( BOUTELLE, p. 42; E. FARAL en ERMOLDO, p. XXXIV) la métrica elegíaca utilizada no permite 
la continuidad narrativa (BOUTELLE, 1970, p. 150, RABY, 1957, p. 223), el tratamiento épico de los sucesos históricos ${ }^{21} \mathrm{y}$ el escaso uso de fuentes, distorsionan sus apreciaciones, si se las compara con la de los otros historiadores carolingios BOUTELLE, (1970, p. 152-156).22

Ermoldo, en su poema, retoma conscientemente la tradición, no solo de raigambre religiosa sino también secular, para elaborar un texto que el autor escribe pensando en su destinatario, Luis el Piadoso e invocando a Cristo, pero poniendo en primer plano tanto su oficio de escritor como su persona (GODMAN, 1987, p. 106, 112; INNES e MCKITTERICK, p. 207). Desde el siglo IX la épica se encuentra integrada al discurso histórico, tal como lo demuestran las crónicas y anales que recurren a sus tramas y personajes para narrar el pasado del mundo franco. De manera particular, el poema en honor de Ludovico es una pieza épica, sus primeros versos son, claramente, una elegiacum carmen de Ermoldo y el resto de las historias narradas conforman un relato épico por excelencia.

Por ello es importante analizar el discurso y sus relaciones con los encuadres de producción, recepción, contenido, tiempo y espacio que le sirven de marco de referencia. Los discursos se encuentran ligados a instituciones y a prácticas sociales determinadas, de allí que conformen estructuras de dominación, sistemas de poder o bien contribuyan a construir el mundo de la experiencia. Y esto es lo que hacen los historiadores del siglo IX. Francine Mora-Lebrun al hablar de Ermoldo, considera que su práctica escrituraria -cuyos modelos serían Virgilio, Prudencio y san Agustín- sustenta un claro proyecto ideológico, que se fundamenta en dos pilares: la traslatio imperii, es decir, la visión de continuidad entre el imperio romano y el imperio carolingio y el encuentro entre política y religión, entre tradición clásica y cristianismo. ${ }^{23}$ Esta autora insiste en la apropiación y reescritura que Ermoldo hace, en especial, de Virgilio, para celebrar poéticamente la liturgia imperial. ${ }^{24}$

En cuanto a Thegan y Astrónomo, los trabajos de Ph. Depreux (20082011), Wolfgang Tenberken (1982) y Ernts Tremp ${ }^{25}$ posibilitan reconstruir sus trayectorias vitales. Ambos tienen como particularidad que recurren a una gran variedad de textos para escribir sus biografías, aunque no siempre sea posible establecer filiaciones con precisión, más allá de las más simples y evidentes. ${ }^{26}$

Ambos brindan datos concretos de la realidad. Por ejemplo, el Astrónomo da información precisa sobre la creciente influencia de los milites en la fragmentación del reino a poco de la muerte de Luis y la necesidad de recaudar tributos para sostenerlos, cosa que no ocurría en tiempos de Carlomagno (ASTRÓNOMO, c.7). 
Numerosos testimonios dan cuenta sobre la transmisión de algunos hechos históricos por la tradición oral. Cuando Thegan se refiere a la información que posee relativa a la ascendencia de Carlomagno, menciona junto a los relatos históricos aquellas otros que había conocido gracias a los comentarios de su propio padre. ${ }^{27}$

También es Thegan (c. 19) quien nos informa sobre el rechazo que Luis siente por los clásicos paganos que había aprendido en su juventud, en especial aquellos poemas de autores clásicos de la Antigüedad romana, cuyo contenido no estaba en armonía con la ética cristiana.

Acerca de la vida del obispo de coro Thegan de Tréveris, las fuentes suministran informaciones relativamente ricas. Él provenía de un distinguido linaje franco, cuyo entorno familiar podría haber existido en el área carolingia central, alrededor del Maas y el Mosela, o bien en las tierras del Rin central. Thegan nació algún tiempo antes del 800 y hacia mediados de la década del veinte se desempeña como obispo de coro. A más tardar a partir del 842, sumó al cargo de obispo de coro la función de deán de San Casio y San Florencio en Bonn, en el vecino arzobispado de Colonia. Su fallecimiento se produjo entre el 849 y 853 .

Dada su actividad orientada al cuidado de almas como también por su posición más bien subordinada en el seno de la iglesia franca y del imperio carolingio, Thegan no estaba de ninguna manera predestinado a escribir una obra de historia acerca del emperador Ludovico. El interés biográfico por la persona del soberano -al haber escrito su obra en vida del mismo- por sí solo no alcanza como justificativo. Que esta obra no se trata una biografía, queda aclarado con el hecho de que el informe comienza con el año 813, el año de la declaración de Ludovico como co-emperador. Su juventud y su significativo accionar por décadas como príncipe-rey en Aquitania permanecen sin mención. Por lo tanto, no registró a la obra con el título Vita Hludowici imperatoris (bajo el cual figura injustificadamente desde la edición de Pertz del siglo XIX), sino con el más adecuado y preciso: Gesta Hludowici imperatoris.

En aquellos puntos en los que Thegan asume posiciones de lucha, no hay objetividad histórica, pese a que también aquí ofrece informaciones absolutamente valiosas e incluso menudas. Thegan pone su prosa puesta al servicio de la causa de Luis, generando discursos que se enfrentan con otros discursos, particularmente en torno a la figura del arzobispo Ebón de Reims.

En cambio, siempre que no sean tocados directamente, ni su concepto político, ni sus animosidades personales, la Gesta Hludowici posee un alto grado de certeza. Informa acerca de los acontecimientos históricos casi sin la 
utilización de fuentes escritas y, ante todo, independientemente de los anuarios imperiales. La ubicación geográfica relativamente retirada y el horizonte intelectual más bien estrecho del autor no ofrecen garantía de fiabilidad y alto contenido informativo de su descripción. No obstante, Thegan contaba con un número de testigos bien informados que lo proveían con noticias de primera mano desde los escenarios de los sucesos. ${ }^{28}$ También sabemos gracias a él que Luis opinaba que la risa no convenía a la dignidad imperial pero que él estaba de acuerdo en ofrecer espectáculos en los banquetes, invitando juglares y músicos (THEGAN, c.19).

A diferencia de la Gesta de Thegan, la Vita Hludowici imperatoris -o también ocasionalmente denominada como "la vida más grande del emperador Ludovico" - ha sido transmitida en forma anónima (TENBERKEN, p. 1 e ss.) y por lo tanto va a ser conocido según c.58 de la Vita, en donde describe en su carácter de astrónomo de la corte la aparición del cometa Halley, en la primavera del 837, y conversa con el emperador sobre ello (ASTRONOMO, c.58). Esto permite calificarlo de "hombre de confianza" de Ludovico el Pío. ${ }^{29}$ Ciertamente era miembro de la capilla de la corte y tenía conocimiento y visión de los sucesos del Imperio. Junto con sus sobresalientes saberes astronómicos, contaba con profundo conocimiento en medicina, era versado en derecho laico y disponía de un alto nivel de formación literaria en general. Pertenecía, como lo formulara Wolfgang Tenberken (1982, p. 11) "a aquellos hombres de la segunda generación de la reforma carolingia, que si bien no contaban con la genialidad y seducción de los precursores, crecidos e influidos por la reforma cultural, llevaron igualmente a cabo buenos logros."

La Vita Hludowici imperatoris fue redactada en los meses entre verano del 840 y primavera del 841 . Esto surge de la postura mediadora que Astrónomo toma con respecto a los hijos: a Lotario le corresponde, como emperador y sucesor de su padre, una posición de preferencia, por otro lado también se reconoce la pretensión de Carlos el Calvo a una parte del imperio y se menciona en términos elogiosos la fraternal concordia entre ambos en 839 (ASTRÓNOMO, c.59, 21.22, c.60, 41-44), mientras que a Luis el Germánico, que fuera desterrado a Baviera, apenas se le concede atención. De tal manera, solo podía escribirse sobre una época cerca de la batalla de Fontenoy, de junio de 841.

La intención de la obra surge claramente de su estructura y de su prólogo. Constituye su temática: la vida y obra de Ludovico, desde el nacimiento hasta la muerte, la juventud, la actividad de gobierno en Aquitania y el dominio en el imperio entero, las tareas como general y los méritos por la reforma eclesiástica, las desilusiones y golpes del destino en el último 
decenio, las últimas horas y el momento de cara a la muerte. De manera inconfundible Astrónomo se apoyó en el modelo que Eginardo había creado con la vida de Carlos. No solo conoció y utilizó la Vita Karoli - como también ya lo hicera Thegan - sino que conformó su biografía monárquica de igual manera, de acuerdo a puntos temáticos esenciales. Mientras que para Eginardo la magnanimitas y la animositas son las que definen el accionar de Carlos como soberano ideal, así Ludovico corporiza para su biógrafo las antiguas virtudes cardinales cristianas de la sobrietas, la sapientia, la iustitia y la virtus, en torno de las cuales se agrupa toda una serie de virtudes de sello cristiano, ${ }^{30}$ parcialmente originadas en el círculo de vida monástico. No obstante, en la profundización de la imagen soberana, Astrónomo trascendió a su modelo y recurrió nuevamente al patrón hagiográfico, que Sulpicio Severo había creado con la Vita S. Martini. ${ }^{31}$ A diferencia de Eginardo, la imagen ideal del soberano cristiano recogida en el prólogo no es siempre fácilmente reconocible, debido a sus sumamente escuetas referencias, a los recursos técnicos utilizados, a la organización de tipo anuario cronológico, organización que se presenta a lo largo de sesenta y cuatro capítulos en la obra equivalentes a sesenta y dos años de la vida de Ludovico. Recién los últimos tres capítulos dedicados a la muerte del emperador (ASTRÓNOMO, c.62 a c.64) vuelven a poner en primer plano los rasgos biográficos básicos, teñidos hagiográficamente, alcanzándose así una conclusión armónica de la obra.

La forma en que son presentados y seleccionados los contenidos ofrecidos en In Honorem, la Gesta y la Vita permiten observar cómo el pasado se transforma en virtud de una "política del pasado", que se apropia de la historia antigua de Grecia y de Roma cristianizándola, convirtiéndola en un "presente eterno" según expresión de Etienne Gilson (1938, p. 222).

Estas recreaciones y relecturas, estas apropiaciones, generan anacronismos que deben considerarse como "necesarios mediadores" entre pasado y presente, dado que posibilitan el traslado de temas, figuras, personajes, instituciones de una realidad pretérita a "lectores" contemporáneos (CORMIER, 1974, p.145-157). Jean Frappier se refiere a ellos como "anacronismos miméticos”, ejemplificándolos en la relación héroe antiguo - nueva moral medieval $^{32}$. El resultado de estas operaciones es una manipulación temporal e ideológica del pasado que elimina los aspectos significativos de la antigüedad para adaptarlos a los tiempos de la sociedad medieval (SPIGEL, p.106).

Aplico seguidamente las reflexiones precedentes al análisis de las nociones de rey y emperador. Los biógrafos subrayan las vinculaciones entre los diferentes grupos nobiliarios (DEPREUX, 1997) entre la propia familia carolingia y la nobleza, ${ }^{33}$ dado que estos textos se escriben pensando en la 
legitimación de la sucesión, de allí la importancia tanto de las completas genealogías como de las vinculaciones con los orígenes troyanos y galorromanos a través de la herencia paterna (MCKITTERICK, 2000, p.164, 169; ASTRÓNOMO, c.7, p.306). El Astrónomo se refiere a la entronización de Luis como rey de Aquitania, en 781 como el resultado de arduas negociaciones entre diferentes grupos nobiliarios, resultado que evidencia la importancia de la aristocracia aquitana (ASTRÓNOMO, c.3).

Thomas Noble se refiere a este "ethos nobiliario carolingio" como a una tradición de santidad secular, cuya elaboración comienza con Eginardo y se continúa hasta el siglo X (NOBLE, 2007, p. 8-36). Esta tradición, sin embargo, no es única ni unánime en cuanto a sus apreciaciones y valoraciones. Por ejemplo, la figura del arzobispo Ebón de Reims ha merecido diferentes tratamientos, entre ellos la hostilidad de Thegan, expresada en la consideración de "servil" aplicada al arzobispo por su relación con Luitardo de Vercelli ${ }^{34} \mathrm{o}$ la consideración de los enemigos internos, que someten a Luis y al reino a toda clase de vejaciones, convirtiéndose en "hombres injustos", "adversarios de la patria" (THEGAN, c.46).

Ebón, los arzobispos Otgario de Maguncia y Agobardo de Lyon y Rigardo defienden la facción de Lotario, facción clerical isidoriana, de la cual el propio Lotario termina siendo víctima. ${ }^{35}$ No obstante, imponen a Luis la humillante penitencia ${ }^{36}$ al acusarlo de sacrílego y homicida de su propia familia, perturbador de la paz y de la integridad del Imperio, degradar la disciplina eclesiástica, conducir a los fieles por caminos equivocados, abusar de su investidura, malgastar armas y recursos en campañas impropias, poner en peligro la paz del reino con sus actitudes temerarias, provocar la ruina del reino por su negligencia e improvisación ${ }^{37}$.

Pero también nos informan y nos dan sus visiones sobre los otros, nos presentean elaborados procesos y mecanismos de construcción de alteridad, desde una perspectiva étnica -enemigo, hereje, mujer del enemigo o del hereje- que llevan a cabo.

Esta construcción de "los otros" es compleja y progresiva, dado que depende tanto de circunstancias históricas concretas como de imaginarios colectivos, que se modelan con el transcurso del tiempo. Nilda Guglielmi ha identificado este conjunto de representaciones como "el imaginario", diferenciándolo de "lo imaginario", que constituye el proceso de reconstrucción y fijación de las imágenes o representaciones (GUGLIELMI, 1991, p. 5-6). Sin dudas, ambos - "el" y "lo" imaginario- se vinculan estrechamente.

Si seguimos a esta autora, considero que el primer cuarto del siglo IX constituye un momento de creación de estas representaciones sobre "los 
otros", en particular sobre "el otro" musulmán, que reúne las caracterizaciones de infiel, salvaje, ladrón, particularmente en Ermoldo y Thegan. En ellos estas representaciones encuentran un punto inicial de fijación, es decir, de construcción de lo imaginario. Las imágenes de sí y del otro que crea y recrea cada sociedad están íntimamente vinculadas a objetos, actos o acciones a las cuales se adjudican determinados valores y sentidos - y también la carencia de ellos-. Cada persona se define y, a su vez, es definida por los demás, con relación a un "nosotros", pero también a un "ellos"/"otros".

Para el caso concreto del Islam, esta definición del "otro" y la consiguiente adjudicación de cualidades específicas fue "prejuicioso" 38 o "imaginario", ya que el Occidente medieval "se representó" a ese mundo a través de imágenes estereotipadas ${ }^{39}$.

Este proceso de construcción de "lo imaginario" no fue ni uniforme ni rápido ni simple, todo lo contrario. Fue un proceso múltiple -que se nutrió de simbologías e "imaginarios" diversos-, que atravesó tres momentos en su proceso de construcción: nacimiento - siglos VIII al XI, difusión - siglos XI al XIV - y declinación - siglos XIV/XV.

Los elementos que subyacen a esta "invención del otro" son de muy variado tipo y remiten tanto a tradiciones orales como a personajes históricos o de leyendas, a valores éticos, a cuestiones religiosas. El cristianismo medieval condenaba la fe musulmana por cuestiones tanto de orden dogmática como por razones de índole moral. Ambas dieron origen a determinadas representaciones del "otro musulmán”, cargadas de una fuerte negatividad ${ }^{40}$, tal como lo demuestran los estudios de Phileppe Sénac, John Tolan, Jean Flori, entre otros. Al respecto, Edward Said afirma que "el Islam se convirtió en una imagen... cuya función no era tanto representar al Islam en sí mismo, como representarlo para el cristiano de la Edad Media"41.

Las representaciones que Occidente realizó de los musulmanes tuvieron como finalidad controlar a un Oriente temible, que al ser "descripto" y "conocido" perdía ferocidad. Se produjo un proceso común en todas las culturas: la "domesticación de lo exótico", la familiarización con lo desconocido, que conllevó una lenta y progresiva pérdida del miedo y del temor al "otro". Este proceso comienza en el mundo carolingio (SÉNAC, 2002; 2006; TOLAN,1996) y encuenta en Ermoldo una de sus primeras elaboraciones narrativas.

Pero estas imágenes tienen otra importante función, la de realzar la auto-imagen a través del reforzamiento de las representaciones del "otro". Estas imágenes, siguiendo a R. Barkaï (1991, p. 13) pueden ser de dos tipos: 
- abiertas: atribuyen al grupo rival un sistema de peculiaridades que no son de un mismo tipo y que no entrañan una percepción estereotipada del mismo;

- cerradas y equilibradas: el grupo adversario es percibido como poseedor de atributos solo negativos ${ }^{42}$. Es el caso de las descripciones contenidas en In Honorem o la Gesta, descripciones carentes de matices en lo relativo a la presentación de los musulmanes, dado que son genéricamente "moros" o "sarracenos".

La construcción de esta alteridad que opone a francos y musulmanes supone, asimismo, la construcción de una determinada memoria. En este contexto me interesa discutir los mecanismos utilizados en la Alta Edad Media para la conservación de la memoria, para la construcción de un pasado que, si bien muchas veces resulta legendario o fabuloso, se revela pleno de historicidad ${ }^{43}$.

Una de estas representaciones, vinculada estrechamente a los procesos de conformación de identidades y de producción ideológica, corresponde a la construcción del "otro" como hereje.

Para Ermoldo, Thegan y el Astrónomo la herejía es, de acuerdo con las Etimologías de Isidoro de Sevilla, error y mentira, derivados de una elección equivocada en materia religiosa, elección que incluye a judíos, cristianos, filósofos y poetas gentiles, magos y paganos en general ${ }^{44}$.

Esta elección, producto del libre albedrío, aleja a los hombres de Cristo, generando infinitos males y justificando diversas acciones militares correctivas. Estos argumentos esgrime Ermoldo para justificar determinadas acciones de Carlomagno y de Ludovico Pío.

En el Libro I rescata la figura de Luis desde su infancia, especialmente por su espíritu religioso, espíritu que le lleva a consultar al alto clero antes de tomar decisiones, restablecer los bienes de las iglesias, administrar rectamente el reino, gobernar a su pueblo con el rigor de la ley y el consejo de la indulgencia (ERMOLDO, I, vv.88-90).

Esto se aplica en relación con la política carolingia respecto de los territorios hispánicos, que remite a la confrontación con vascos y moros, dos pueblos a los que se identifica con "los otros" desde una perspectiva religiosa y, por lo tanto, heréticos.

Los vascos merecen unos breves comentarios despectivos, dado que son presentados como "lobos salvajes" (ERMOLDO, I, v. 93), sometidos a los francos por la gracia divina ${ }^{45}$. Estos vascos, una vez sometidos, luchan junto a los carolingios en el sitio de Barcelona (800-801) contra los musulmanes (ERMOLDO, I, v. 313). 
El panegírico In Honorem da cuenta de este doble proceso de construcción de la identidad y de lo imaginario, a partir de la presentación de imágenes estereotipadas del "otro". De esta forma, queda conformado un "nosotros", franco y cristiano, que se define y delimita a partir de un "los otros", enemigos de fe, esencialmente musulmanes, cuyas características distintivas son la idolatría (FLORI, 1992, p. 245-256) y la apostasía (TOLAN, 1996, p. 115-157).

El mencionado sitio de Barcelona ofrece la posibilidad a Ermoldo de desarrollar toda una gama de argumentos y descripciones tendientes a realzar la auto imagen y denostar la del enemigo. Tras la toma de la ciudad,

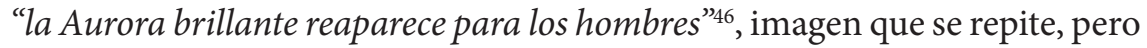
reforzada su valencia, más adelante cuando afirma que "la Aurora brillante" desplaza a los moros, "hombres de la noche" (ERMOLDO, I, v. 156-163). De esta manera, luces y sombras, luminosidad y nocturnidad, blancura y negrura serán atributos de los francos y los musulmanes, de los buenos y de los condenables respectivamente.

Al comenzar la campaña, Carlomagno exhorta a los señores a tomar las armas para defender "las fronteras de la patria" ante el ataque de "otras naciones" (ERMOLDO, I, v. 501-503). El duque Guillermo de Tolosa nombra a esas otras naciones como "los hijos de Sara"47 y los acusa de haber sometido por la fuerza "ciudades, castillos y plazas" (ERMOLDO, I, v. 174-191).

Un ejemplo de este sometimiento lo ofrece el monasterio de Conques y su entorno. El monasterio - fundado, según Ermoldo, por Luis en el año 800 - tuvo en Datus a su primer religioso allí instalado. Él enfrenta a los moros, quienes en búsqueda de botín, asaltan, saquean, someten y humillan la región. Gran parte de la población es masacrada y, para doblegar la resistencia de Datus, llegan a cortar la cabeza de su madre ante sus propios ojos (ERMOLDO, I, v. 224-301).

Los moros, además de salvajes, merecen el calificativo de ladrones (ERMOLDO, I, v.106), dado que han sometido al pillaje a vastas zonas de la región catalana y destruido olivares y viñedos, pasturas, ganado, villas, castillos y poblaciones. Es necesario someterlos, para restablecer la paz en los dominios fronterizos. Y esa paz y tranquilidad se logran "merced a la gracia de Dios" (ERMOLDO, I, v. 188), que, de esta manera, obra a través de Luis. Esta noción se reitera en varios pasajes de la obra y refuerza la vinculación entre los planos espiritual y material, celestial y terrenal, eclesial e imperial.

Otro calificativo que reciben los moros es el de infieles, aunque no se precisan las razones del mismo (ERMOLDO, I, v. 208). Sin embargo, las arengas que los distintos jefes realizan ante el sitio de Barcelona ofrecen indicaciones al respecto, dado que mientras las tropas cristianas "agradan 
a Cristo" y "honran a Dios", los moros "obedecen y están comandados por el demonio", de allí que sean considerados como "un pueblo execrable" (ERMOLDO, I, v. 323-333).

Luego de luchas épicas y parlamentos heroicos - que remiten a la tradición virgiliana ${ }^{48}$-, la ciudad se rinde y tras varias jornadas de fiestas

el rey Luis entra triunfal, seguro de estar defendiendo a Dios: purifica los templos en donde los moros ofrecieron sacrificios al demonio y ofrece acciones de gracias a Cristo. Pues, merced a la intervención divina, entra victorioso a la guarnición, habiendo dejando en tierra sus armas. (ERMOLDO, I, v.567-571)

Estos parlamentos permiten realzar la figura de los francos, ya que hasta los propios moros reconocen su superioridad. Así lo manifiesta, por ejemplo, Zado, quien ve en ellos a un pueblo valiente, enérgico y belicoso, de acuerdo a una larga tradición que asociaba el nombre propio, franco, a ferus, vocablo cuyos significados son indómito e indomable (ERMOLDO, I, vv.372-373; Cf. ISIDORO DE SEVILLA, Etimologías, IX, 2, 101, v. 1, p.758).

En otra oportunidad, es el moro Durzaz el que reconoce en los francos esta fuerza indómita, cuando se pregunta por qué "un pueblo invencible, que domina el mundo entero, ataca la piadosa ciudad (de Barcelona)" (ERMOLDO, I, v. 390-391). Sin duda, concluye, "los bravos francos" intentarán someter a los musulmanes (ERMOLDO, I, v.394).

Estas descripciones acompañan las que presentan las batallas por entrar a la ciudad. Los combates son duros y dejan sin respuesta a los defensores de las murallas: "los moros aterrados" no pueden actuar frente a los francos y "huyen temblando", temiendo por sus vidas (ERMOLDO, I, v. 538 y v.548).

A lo largo del panegírico, se presentan las diversas empresas que Luis lleva a cabo, empresas militares y diplomáticas de las que sale victorioso. Esto se debe a que la nación franca "triunfa por su amor a Dios y por su $f e$ " (ERMOLDO, III, v. 1407) o bien, como subraya luego el texto, el reino se consolida "gracias a Cristo", que permite que se fortifiquen "el amor y el respeto a Dios" (ERMOLDO, III, v.1787).

De esta manera, la fe es un elemento determinante de la identidad y unidad de un pueblo, patria o nación. Identidad y unidad que tienen, a su vez, raíces históricas, raíces que muchas veces se encuentran tan ramificadas o hundidas en el pasado que resulta muy difícil determinar su autenticidad o veracidad, pero que la escritura de un poeta o de un historiador - y Ermoldo es ambas cosas a la vez - contribuye a fijarlas en las mentalidades y constituirlas en ideología. 
El sometimiento de britanos o bretones, desarrollado en el Libro III de In Honorem, permite a Ermoldo reafirmar esta relación entre Dios y los francos: Luis lleva la paz a las fronteras, tras enfrentarse y derrotar a esta nación, que el texto califica de "pérfida e insolente", que tiene de cristiana solamente el nombre. Las figuras de Murman y su mujer estructuran esta parte del relato. En particular, la figura de la esposa del lider de los bretones que, con sus palabras y actitudes temerarias, carentes de toda razón, genera tensiones y conflictos.

Los historiadores de la novena centuria nos han transmitido también en este caso visiones de figuras opuestas, dado que la reinas y damas de corte son presentadas con rasgos positivos en tanto las mujeres de los líderes o nobles opositores son retratadas de manera negativa (NELSON, 1996, p.183197). En esta oportunidad indagaré sobre las imágenes que Ermoldo nos transmite de la mujer del líder de los bretones Murman. Frente a Ermengarda, Judith y las mujeres francas, ${ }^{49}$ que son amadas por Dios y que retribuyen este amor con sus vidas honrosas y entregadas a sus maridos, se encuentran las despreciables mujeres de los bretones, pueblo contra el que llevan a cabo varias campañas militares.

La primera de ellas ocurre en 818-819. Antes de comenzar las primeras acciones diplomáticas y bélicas, Luis, atento a imitar los ejemplos de sus mayores, interroga a Lamberto, conde de Nantes, a quién pregunta:

¿Qué culto rinde esta nación al Señor? ¿Qué fe profesa? ¿Qué honores disfrutan en ella las iglesias del verdadero Dios? ¿Qué pasiones animan a este pueblo? ¿Ama la justicia y la paz? ¿Respeta la monarquía? ¿Merece nuestra bondad? ¿Han sufrido nuestras fronteras algún menoscabo por su parte? (ERMOLDO, III, v.1285-1293).

Ante este interrogatorio, Lamberto se inclinó, abrazó las rodillas del emperador y respondió:

Esta nación engañosa y soberbia se ha mostrado hasta ahora rebelde y sin bondad. En su perfidia, el bretón no conserva de cristiano más que el nombre. Las obras, el culto, la fe no existen para ellos. Los huérfanos, las viudas, las iglesias nada esperan de su caridad. En este pueblo, el hermano y la hermana viven en una infame unión, el hermano se lleva a la mujer de su hermano, todos practican el incesto y ninguno retrocede ante ningún crimen. Habitan en los bosques, no conocen más retiro que las cavernas y ponen su felicidad en vivir de la rapiña, como las feroces bestias. La justicia no es, entre ellos, objeto de culto y han rechazado cualquier idea de lo justo y lo injusto. Murman es su rey, si se puede llamar rey a aquel

Hist. R., Goiânia, v. 17, n. 2, p. 69-103, jul./dez. 2012 
que no toma decisiones por su propia voluntad. Frecuentemente han osado llegar hasta nuestras fronteras, pero nunca han vuelto a las suyas sin ser castigados por esta temeridad. (ERMOLDO, III, v. 1294-1311).

Bestialidad y falta de todo espíritu cristiano es lo que caracteriza al bretón, que se reflejan en la práctica del incesto, repudiable para los francos (BRUNDAGE, 2000; POLY, 2003) y que se repiten al describir la embajada de Witchaire ante Murman, rey de los bretones.

Esta embajada tiene por finalidad obligar a pagar tributo a los bretones y castigarlos por sus horrendos crímenes. El emperador llamó entonces a Witchaire, hombre probo, hábil y sabio, le dijo:

Corre, lleva al tirano de ese pueblo nuestras órdenes soberanas. Respétalas en los términos en que te las decimos y confiamos. Hazle ver que el efecto seguirá a la amenaza. Él y los suyos cultivan en nuestro imperio vastas tierras, donde las aguas los arrojó como a miserables exiliados condenados a una vida errante. Sin embargo, nos niegan un tributo justo, quieren combatir, insultan a los francos y mueven contra ellos sus armas. Desde que, por la bondad de Dios y por la demanda de toda la nación, subimos al trono de nuestro padre y ceñimos la corona imperial, hemos soportado la conducta de este rey, esperando siempre que se mostrara fiel y viniera él mismo a solicitarnos nuestras leyes. Pero tras tanto tiempo, ese espíritu pérfido duda en cumplir con su deber y, para colmo, he aquí que toma las armas y provoca guerras criminales. Ya es hora, ya es más que hora, de que ese desgraciado cese de abusar. Él y los suyos. Que se dé prisa en venir humildemente a pedir la paz a los francos. Si se negara, vuela y vuelve para hacernos un informe fiel y detallado (ERMOLDO, III, v.1324-1341).

Murman y Witchaire finalmente se encuentran y tras el intercambio de saludos formales y de rigor, se sientan, dando comienzo al encuentro. Toma la palabra el representante del emperador:

Luis, que proclama al universo la gloria de los francos, el honor del nombre cristiano, sin igual en el amor a la paz y en la fe a su palabra, sin rival tampoco en la guerra, el primero de los príncipes por su ciencia y su piedad, me envía a tí, Murman. Tú y los tuyos cultiváis en su imperio vastas tierras donde la mar os arrojó como a miserable exiliados condenados a una vida errante. Sin embargo, le niegas un tributo, quieres combatir, insultas a los francos y mueves contra ellos tus armas. Ya es hora, ya es más que hora, infeliz, de que ceses de abusar, tú y los tuyos. Por lo tanto, apresúrate a demandar la paz. Te he repetido las propias 
palabras del César. Añadiré algunas, Murman, pero que proceden sólo de mí y que son dictadas por mi apego a ti. Si ejecutas sin tardanza y sin que nada contraríe las órdenes de mi príncipe, como él mismo te invita en su bondad, si deseas conservar con los francos una paz eterna, como lo reclaman y lo mandan tu propio interés y el de los tuyos, parte ahora mismo, corre a recibir las leyes del piadoso monarca y llévale los tributos que tú debes a él sólo y sobre los cuales no tienes ningún derecho. Piensa, te lo pido, en tu patria, en todo tu pueblo, piensa en tus hijos y en la mujer que comparte tu cama, piensa sobe todo que tu nación y tú cometéis el error de adorar vanos ídolos, de violar los santos mandamientos, de seguir los caminos del demonio. Puede que el piadoso rey te reintegre a tus campos, que entonces serán de tu propiedad, puede que te colme de dones más considerables aún. Supongo que serás más poderoso de lo que eres, que tu imperio se extenderá sobre tierras más vastas, que tendrás un mayor número de soldados y un ejército mejor equipado (ERMOLDO, III, v.1370-1394).

Murman, atento, tenía su frente y sus ojos fijos en la tierra, que golpeaba con su pie. Ya Witchaire con su hábil discurso y sus amenazas insinuadas con arte, había ablandado al bretón, que dudaba aún en sus proyectos.

De golpe, la mujer de Murman, pérfida y de corazón emponzoñado, sale de la alcoba nupcial y viene con aire soberbio a solicitar los acostumbrados saludos de su esposo. Le besa la rodilla, la barba, el cuello y presiona con sus labios el rostro y sus manos. Va, viene, revolotea en torno a él, le prodiga -mujer hábil- las más ardientes caricias, se esfuerza con una insidiosa solicitud en proporcionarle mil pequeños y tiernos mimos. Por fin, el infortunado la acoge en su regazo, la aprieta entre sus brazos, cede a sus deseos y se abandona a sus dulces caricias. Entonces la malvada se engancha a su oreja, le habla en voz baja durante un rato y pronto lleva la turbación a los sentidos y al espíritu de su esposo. Como cuando en mitad de los bosques y en la estación de la escarcha un grupo de pastores procuran encender un fuego con la madera cortada por el hacha, que uno lleva los trozos más apropiados para prender, otro arroja paja en medio del combustible más seco, el tercero anima el fuego con su soplo y pronto chisporrotea, se enciende, suben las llamas hasta los astros; los miembros helados del pastor se calientan; pero de repente ruge la tormenta, el granizo, la lluvia, la nieve caen con estrépito y todo el bosque resuena con los estampidos del rayo: el fuego sucumbe bajo los torrentes de agua y la hoguera sólo proporciona, en lugar de calor, una espesa humareda. Así, esta mujer, que lleva la desgracia con ella, ahoga en el corazón de su esposo el efecto de las palabras de Witchaire (ERMOLDO, III, v.1414-1439).

Hist. R., Goiânia, v. 17, n. 2, p. 69-103, jul./dez. 2012 
Le pregunta a Murman de dónde viene este huésped, cómo ha llegado hasta el palacio y si trae palabras de paz o de guerra. Murman, sonriendo, le responde en términos ambiguos: "Este emisario viene de parte de los francos. Que traiga la paz o la guerra es asunto de hombres. En cuanto a ti, mujer, no pienses más que en cumplir, como debes, con los cuidados que pertenecen a tu sexo" (ERMOLDO, III, v. 1447-1449).

Tras lo cual, Murman rechaza las peticiones del emperador Luis:

Date prisa en llevar esta respuesta a tu rey: los campos que cultivo no son suyos y no deseo acatar sus leyes. Que él gobierne a los francos. Murman manda legalmente a los bretones y rechaza cualquier tributo. Que los francos se atrevan a declarar la guerra, y sobre el campo, yo también lanzaré el grito de combate y les mostraré que mi brazo no es aún tan débil (ERMOLDO, III, v.1464-1469).

Witchaire replica a Murman y, al hacerlo, lo hace insistiendo sobre la debilidad del monarca bretón, que cede a las palabras de una mujer: "Es suficiente una mujer para moldear el ánimo de un hombre como blanda cera y para substituir por vanos propósitos los consejos de la prudencia"(ERMOLDO, III, v.1470-1475).

Murman, con el corazón pleno de rabia, se levanta furioso del trono de los bretones, respondiendo con altivez: "Contra las desgracias con las que me amenazas, tengo miles de carros, y a su cabeza me lanzaré yo, hirviendo de furor, ante vuestros golpes. Vuestros escudos son blancos, pero yo les podré oponer otros muchos recubiertos de un sombrío color: la guerra no me inspira ningún temor" ERMOLDO, III, v.1492-1497).

Tras la fallida embajada, francos y bretones se preparan para el combate en torno a la ciudad de Vannes. Pronto están allí todos los pueblos conocidos bajo el antiguo nombre de francos: familiarizados con la guerra, tienen preparadas las armas y las llevan con ellos. Miles de suevos de rubia cabellera, agrupados en centurias, vienen de más allá del Rin. Allí están las falanges sajonas, de grandes aljabas y con ellas marchan las tropas de Turingia. Borgoña envía una juventud diversamente armada, que se mezcla con los guerreros francos, que aumentan, así, su número.

En el fondo de los valles, umbrosos por el tupido monte bajo, aquel fiero bretón excita sus caballos, toma sus armas habituales, exhorta a los suyos con un aire triunfal, les reprocha su lentitud y hace oír estas palabras soberbias:

Vosotros, mi mujer, mis hijos, mis servidores, permaneced sin miedo en vuestras residencias sombreadas por los bosques. Yo, secundado por un 
pequeño número de guerreros, iré adonde con más seguridad pueda pasar revista a mis batallones y, pronto, espero, mi veloz caballo me traerá de nuevo a mi techo doméstico, cubierto de trofeos y cargado de despojos (ERMOLDO, III, v.1622-1627).

Entonces, pleno de confianza, solicita, según es habitual, delante de todos sus servidores que lo rodean, los abrazos de su mujer y sus hijos y les dedica unas prolongadas caricias.

A continuación, blandiendo con violencia las jabalinas con las que sus manos están armadas, exclama:

Mujer de Murman, recuerda lo que te voy a decir: ves, mi bienamada, las saetas que tiene en las manos tu esposo, animado por la alegría y ya sobre su caballo. Si mis presentimientos no me engañan, las verás hoy a mi vuelta teñidas con la sangre de los francos. Te lo juro, objeto de mi ternura: el brazo de Murman no lanzará ninguna jabalina que no haga blanco. Adiós, esposa querida, adiós. Pórtate bien (ERMOLDO, III, v. 1636-1643).

Ante tanto alboroto y movimiento de hombres y armas, Luis decide intentar un nuevo diálogo con Murman: "César, movido de nuevo por esa religiosa piedad que en él es habitual, manda a un mensajero que vaya a toda prisa para poner otra vez ante los ojos de los bretones los males que los amenazan" (ERMOLDO, III, v. 1644-1645).

El nuevo mensajero corre al encuentro con los bretones, que lo rechazan "reafirmado en sus funestas ideas por las solicitaciones de su orgullosa mujer, responde en términos duros y muestra un corazón cautivo del odio. Desea la guerra, convoca a todos los bretones, dispone emboscadas y prepara pérfidas artimañas" (ERMOLDO, III, v. 1676-1687).

Francos y bretones libran feroces batallas y en una de ellas, un franco humilde, Coslus, hiere de muerte a Murman, al clavarle con fuerza la lanza en sus sienes. Tras esta muerte, los bretones se rinden, no sin antes recordar que estas desgracias ocurrieron por la ciega confianza que Murman prestaba a los consejos de su mujer.

Los bretones se ven en la necesidad de ir a pedir ellos mismos el yugo del rey franco y, con ellos, comparecen los hijos de Murman y toda su estirpe. El triunfante Luis recibe en el mismo campo el juramento de los bretones, les dicta sus leyes, les confirma su fe y les devuelve así la paz y la tranquilidad. Este príncipe victorioso rinde inmediatamente profundas 
acciones de gracias al Señor, agrega a su corona un reino desde hace tantos años perdido para el imperio.

Thegan (c.15; c.27) utiliza expresiones similares al referirse a los eslavos de Oriente.

De esta manera, la fe y el dogma se constituyen en elementos determinantes de la identidad y unidad de un pueblo de de una nación. Identidad y unidad que tienen, a su vez, raíces históricas. Por ello, considero posible compartir la tesis de W. Goffart (p.3-19), según la cual los "historiadores bárbaros" generaron un relato historiográfico recurriendo a diferentes fuentes y técnicas narrativas, que los convierten en verdaderos historiadores, desde una concepción moderna de la profesión: en el reino de Luis el Piadoso se genera una historiografía de corte, crucial para comprender la imagen pública y política de la monarquía y del monarca (INNES, MCKITTERICK, p.209).

La construcción de una tradición franco-carolingia, a partir del análisis de las relaciones entre literatura e historia, remite al análisis del discurso, análisis que no puede entenderse como el estudio de una fórmula pura y perfecta sino que debe considerar los encuadres de producción, recepción, contenido, tiempo y espacio que le sirven de marco de referencia, en este caso, la producción histórica y literaria de la "renovación cultural carolingia", caracterizada por los fuertes lazos que vinculan la épica (MORRISEY, 1997, p.73) ${ }^{50}$ y la teología (MCKITTERICK, 1990, p. 10) con la historia.

Jean Batany (1981, v.1, p.313-340) afirma que el proyecto ideológico-político que se evidencia en Ermoldo y que subyace en los fundamentos de la "propaganda carolingia" del siglo IX, derivó, con el devenir del tiempo, en el "mito carolingio" del siglo siglo XII (BATANY, 1982, v.1, p. 313-340).

Esta construcción del "mito carolingio" supuso reapropiaciones, resignificaciones, omisiones, silencios, interpolaciones, agregados. Y así como ciertos personajes se convirtieron en fundantes, otros, en cambio, fueron caracterizados negativamente. En particular, esta deconstrucción y construcción de la figura de Luis signficó la vulgarización de su imagen. Se cuestiononaron sus aptitudes como gobernante y los atributos de carácter que el Astrónomo había tratado de hacer aparecer bajo una luz positiva (ASTRONOMO, Prólogo), se convertían, en contraste con el dinámico Carlos, cada vez más en "Luis el Piadoso", en el demasiado bondadoso y débil epígono, ${ }^{51}$ que sigue viviendo como tal en el uso idiomático del francés y en la conciencia histórica hasta el día de hoy. 
EPIC, MEMORY AND HISTORY: HOW THE CAROLINGIAN WROTE THE WORLD

Aвstract: In the works of the Carolingian historians of the ninth century, Louis appears not only as the successor of Charlemagne, but, especially, as a monarch who aspires to the continuity of the Renovatio Regni Francorum. That is why these authors do not say anything randomly as they are the expression of a genuine ideological, cultural and political project. Hence I consider such works as "constructed objects", which serve not only to interpret a reality but also to create it. The construction of a Franco-Carolingian tradition, based on the analysis of the relationship between literature and history, relates to the analysis of discourse. This kind of analysis can not be understood as the study of a pure and perfect formula but rather of the production frames, reception, content, time and space that will provide a frame of reference, in this case, the historical and literary production of the "Carolingian cultural renewal", characterized by strong ties that bind epic and theology with history.

Key Words: Franks, Carolingian, Louis the Pious.

\section{NOTAS}

1 Este trabajo forma parte de los proyectos "Literatura e Historia en la Épica latina de la Tardía Antigüedad y Alta Edad Media", financiado por la Agencia Nacional para la Promoción Científica y Tecnológica en el programa PICT 2007, No01525, del 12/06/09 al 11/06/12, según Resolución ํo320/08 y "Rupturas y continuidades de la Épica", PGI 24/I175, del 01/01/09 al 31/12/11, ambos dirigidos por el Dr. Rubén Florio y radicados en el Departamento de Humanidades de la Universidad Nacional del Sur. Una versión original fue presentado en el Bi-Congreso Internacional de Estudios de Historia Clásica e Historia Medieval, Octavas Jornadas de Estudios Clásicos y Concilivm Medii Aevii organizados por la Universidad del Bío Bío y Sociedad Chilena de Estudios Medievales en San Bartolomé de Chillán los días 28, 29 y 30 de abril de 2011. Quiero agradecer a todos los organizadores por la invitación y el trato recibido, especialmente al Dr. Luis Rojas Donat. Hago extensiva esta deuda de gratitud al Dr. José Marín Riveros y al Lic. Diego Melo Carrasco.

2 En este sentido resulta pionero el trabajo de Rosamond MCKITTERICK, The Frankish Kingdoms Under the Carolingians, 751-987, Londres, Logman, 1983.

3 A modo de síntesis cf. CORRADINI; MEENS: PÖSSEL; SHAW, 2006; GAZEAU; BAUDUIN; MODÉRAN, 2008.

4 Estos estudios comenzaron con las investigaciones de Percy Ernst SCHRAMM, Die deutschen Kaiser und Könige in Bilden ihrer Zeit, 751-1190, Munich, Prestel, $1983,2^{a}$ edición ( $1^{\text {a }}$ edición 1928). A esta obra pionera y en cierto modo anticipatoria en todo lo relativo a las imágenes y símbolos del poder en la Edad 
Media le siguieron las de Ernst KANTOROWICZ, Laudes Regiae: A Study in Liturgical Acclamations and Medieval Ruler Worship, Berkeley and Los Angeles, University of California Press, 1946; Ernst KANTOROWICZ, The King's Two Bodies: A Study in Medieval Political Theology, New Jersey, Princeton University Press, 1957. Entre los varios trabajos de especialistas ingleses, alemanes, franceses y norteamericanos destaco: Michael McCORMICK, Eternal Victory: Triumphal Rulership in Late Antiquity, Byzantium, and the Early Medieval West, Cambridge, Cambridge Univerity Press, 1990; Janet NELSON, The Frankish World, 750-900, Londres, Hambledon Press, 1996; Gerd ALTHOFF, Spielregeln der Politik im Mittelalter: Kommunikation in Frieden und Fehde, Darmstadt, Primus-Verlag, 1997; Philippe BUC, The Dangers of Ritual: Between Early Medieval Texts and Social Scientific Theory, Princeton, Princeton University Press, 2001; Gerd ALTHOFF, Johannes FRIED and Patrick GEARY (ed.), Medieval Concepts of the Past. Ritual, Memory, Historiography, Washington D.C. and Cambridge, German Historical Institute and Cambridge University Press, 2002; Gerd ALTHOFF, Die Macht der Rituale: Symbolik und Herrschaft im Mittelalter, Darmstadt, Primus-Verlag, 2003; Joanna STORY (ed.), Charlemagne: Empire and Society, Manchester, Manchester University, 2005.

5 A modo de síntesis de estas nuevas miradas cf. Rosamond MCKITTERICK, 1990; Jennifer DAVIS and Michael McCORMICK, 2008; Wojciech FALKOWSKI, Yves SASSIER, 2009.

6 Al respecto cf. los estudios modélicos de Rosamond MCKITTERICK, (2008) y Georges MINOIS, (2010).

7 NELSON, (2008, p.223-234) considera esenciales a los obispos en todo lo referido a la articulación de los poderes locales y el Imperio. Cf. Carine van RHIJN (2007). Por su parte, R. MCKITTERICK, (2008, p.295-315) habla de la importancia de la topografía sagrada en el reino franco y la relaciona tanto con el papel de los obispos como con las reformas en la Iglesia y el triunfo de la ortodoxia. En tanto, Dominique IOGNA-PRAT (2006) vincula fuertemente la difusión del poder político carolingio con la consolidación material del cristianismo, debido al avance de las construcciones cristianas (iglesias, basílicas, catedrales).

8 ERMOLDO, IV, vv.267-282. Por su parte, ASTRÓNOMO, c.21-22 se refiere a la importancia de la tradición imperial romana en la corte carolingia, tradición que sobrevive pese a la creciente cristianización del Imperio

9 Gabrielle SPIEGEL (1999 p. XVIII) subraya la importancia del lenguaje performativo al momento de analizar y considerar los textos medievales. Más adelante (p.3-28), fundamenta y ejemplifica la relación existente entre "realidad", "contexto", "estructura social” y el marco analítico elaborado por los historiadores, relación que necesariamente habla de textos y se expresa a través de textos. Cf. Robert F. BERKHOFER, 1997. 
10 R. MCKITTERICK (2008, p. 345-372) se refiere "libros reales" al referirse a la vasta cantidad de manuscritos que se producen, copian o guardan en la corte o ámbitos cercanos a ella. Cf. HEIDECKER, 2000; GOETZ, 2000.

11 Mayke de JONG (2009, p. 59) se refiere a la obra de estos autores como "narrativas de la novena centuria" en tanto Thomas NOBLE (2009) los considera genéricamente "biógrafos".

12 Tomo y adapto la noción de "función social de la prosa" elaborada por Gabrielle SPIEGEL (1993). Para esta autora, el recurrir a la prosa como medio para escribir historia en los siglos XII y XIII constituye una operación de tipo ideológico, de parte de un grupo de la élite, que prentende o reclama su propia legitimidad histórica, de allí que reemplacen al latín por la lengua vulgar.

13 La LIX Setimana di studio de Spoleto (28 de abril - 4 de mayo de 2011) se convoca con el título de "Scrivere e Leggere nell'Alto Medioevo".

14 Chris WICKHAM (2009, p. 411): la importancia política de este grupo se observa en sus obras y textos justificatorios o laudatorios, en las excusas, en la promoción de dterminados personajes.

15 La propuesta problematizadora de esta cuestión puede verse en Michel BENNIARD, 1990, p.695-708.

16 Sobre estas cuestiones resulta modélica la tesis de doctorado de Patricia ROCHWERT-ZUILI, Du poème a l'histoire. La geste cidienne dans l'historiographie alphonsine et neo alphonsine (XIIIéme-XIVéme siècles), defendida en 1998 en la Université Paris XIII. Ver también la recopilación a cargo de Victoria CIRLOT (comp.), Epopeya e Historia, Barcelona, Argot, 1985.

17 Cf. en este mismo sentido los trabajos de Michael CLARCHY, 1993; Janet COLEMAN, 1992; Elisabeth van HOUTS, 2001.

18 Cf. Brian STOCK, 1996, p.16-29.

19 WERNER, p.116,118. Cf. FARAL, en: ERMOLDO, pp.V-XXX; C. FLEINER, In Honor..., p.12 considera que Ermoldo pertenece a la corte del rey Pipino de Aquitania (797-838) y de Luis el Piadoso (814-840).

20 MURATORI (ed.), In Honorem Hludowici, en: Scriptores rerum italicarum, II. Ermenaldus recibe dos cartas de Luis el Piadoso como abad de Aniane, en 835 y 837, p.6.

21 BOUTELLE (1970, p. 152) afirma que este tratamiento lleva a que la evidencia histórica se altere, dado la magnificencia que se le otorga a los diferentes acontecimientos.

22 A diferencia de Thegan y Astrónomo que recurren a los textos que tienen a disposición en la biblioteca de la Corte, Ermoldo recurre a la tradición oral.

23 MORA-LEBRUN, 1994, p.124. Sobre los modelos insiste en la influencia de la himnodia cristiana, pp.248-249, que llegaría a Ermoldo a través de la mediación

Hist. R., Goiânia, v. 17, n. 2, p. 69-103, jul./dez. 2012 
de Karolus Magnus et Leo Papa, p.126. En cuanto a la relación con Prudencio, compara las referencias a Mateo, 8, 23-27 (la tempestad calmada) en Contra Símaco, Prefacio, L.II, vv.23-43 y Ermoldo, vv.58-63, pp.126-127, nota 97. Considera que a Ermoldo puede aplicársele el mismo título que a Prudencio: "maestro de la epopeya latina asociado a la cristiandad", pp.157-158.

24 MORA-LEBRUN, 2006, p.85-97, en particular pp.89 y 96 donde recurre a la expresión "Virgile amélioré".

25 TREMP, 1990, p. 691-700, además de los estudios antes indicados.

26 AIRLIE, 2007, p.72. Rosamond McKitterick estudia la importancia de las versiones " $D$ " y particularmente " $E$ " de los Annales regni francorum en Thegan y Astrónomo, en Rosamond MCKITTERICK, 2006, p. 63-89. Cf. M. INNES and R. MCKITTERICK, “The writing...", p.216 subrayan la importancia de la transmisión y la reescritura de la historia en el siglo IX y recurren para ello al análisis divergente que sobre la crisis de 830 plantean el Astrónomo y Nitardo. Ver algunas de estas cuestiones en Reinhold RAU (ed.), 1968-1969.

27 THEGAN, c.1: "sicut paterno relatu didicimus et multe testantur historie".

28 A pesar de lo dicho, el editor de Thegan en el siglo IX, Walafrido Estrabón cuestionaba esta objetividad. Cf. Eleanor DUCKETT, 1962, p.149.

29 M. INNES and R. McKITTERICK, “The writing...”, p.210 se refieren a él como escritor oficial, dado que su texto tiene por objetivo justificar en un texto público la política oficial, para lo cual utiliza otros textos que tiene a disposición en el archivo de palacio, en especial Drogo de Metz. Cf. ASTRÓNOMO, c.63.

30 ASTRÓNOMO, c.55 compara a Luis con David, ambos son magnánimos y solícitos; el emperador franco lo demuestra en ocasión de la peste que azota Italia en 836-837.

31 Sulpicius Severus, Vita S. Martini, cuyo texto se encuentra en el volumen 20 de la Patrología Latina y está próximo a ser editado críticamente en la Series Latina del Corpus Christianorum. Cf. Sulpicius Sévère. Vie de Saint Martin, Introduction, texto et traduction par Jacques FONTAINE, 3 volúmenes, París, du Cerf, 1967-1969.

32 Jean FRAPPIER, "Peinture de la vie et des héros antiques dans la littérature française du XIIe et du XIIIe siècle", en: Jean FRAPPIER, Histoire, mythes et symboles: études de littérature française, Génova, Publications Romanes et Française 137, 1976, pp.21-54.

33 Cf. Regine LE JAN (ed.), La Royauté et les elites dans l'Europe carolingienne (du début du VIIIe siècle aux environs du 920), Lille, Centre d'Histoire de l'Europe du Nord-Ouest, 1998. THEGAN, c.2 precisa, por ejemplo, la importancia de estos lazos nobiliarios en todo lo referente a la legitimación y sucesión de Carlomagno a partir de su matrimonio con Hildegarda; en c.25-26 se refiere al casamiento de Luis con Judith, proveniente de un noble linaje de Baviera. 
34 THEGAN, c.43, c.50 en los cuales identifica claramente a este arzobispo como cabeza de una facción nobiliaria y lo responsabiliza de la inestabilidad institucional de de la década del treinta. Incluso en el c.43 se refiere a él como "hombre cruel".

35 MAGNOU-NORTIER, 1999, p. 331-365 y p.615-642, en especial 2a parte, p.625 donde se refiere al "régimen episcopaliano". ASTRÓNOMO, c.51 considera a Ebón impulsor de la pena pública impuesta a Luis en 833. THEGAN, c.47 se refiere a Otgario y Rigardo como "perfidus".

36 É. MAGNOU-NORTIER, “La tentative...", $1^{\text {a }}$ parte, p. 335 considera que esta pena es la forma de aplacar la cólera de Dios, tal como se expresa en la penitencia impuesta a Judith, acusada de adulterio por sus enemigos. Cf. THEGAN, c.36, ASTRÓNOMO, c.44 y NITARDO, I, c.2. Para Luis, esta penitencia (tonsura y exilio) tuvo por finalidad "mitigar la discoria" en palabras de THEGAN, c.24.

37 É. MAGNOU-NORTIER, “La tentative...”, 2a parte, p.640 considera la penitencia impuesta a Luis como "el primer proceso de tipo stalinista de la historia de Occidente". Cf. Maike de JONG, "Power and humility in Carolingian society: the public penance of Louis the Pious", en: Early Medieval Europe Vol. 1, №1, 1992, pp.29-52; M. de JONG, The Penitential State....

38 Hichen DJAÏT, Europa y el Islam, Madrid, Libertarias, 1990, p.39; R. BARKAÏ, Cristianos..., p.285.

39 Philippe SÉNAC, L'image de l'autre. Histoire de l'Occident médiévale face à l'Islam, París, Flammarion, 1983, pp.8-9.

40 Una puesta al día de la bibliografía de referencia sobre esta cuestión puede verse en LUTZ-BACHMANN und FIDORA (hrsg.), 2004. Cf. BARKAÏ, 1994.

41 SAID, 1990, p.87; TOLAN, 2003, p. 115-237 habla de la "invención de imágenes polémicas" al referirse a esta construcción entre los siglos VIII y XII.

42 Ron BARKAÏ, Cristianos y musulmanes en la España medieval (El enemigo en el espejo), Madrid, Rialp, 1991, 2a edición ( $1^{\text {a }}$ edición en inglés 1984), p.13.

43 MONTANER, 1993, p. 19 afirma que "el papel de la memoria no era sólo recordar las glorias del ayer, sino presentar las bases del hoy".

44 Cf. el Libro VIII de las Etimologías, 1993, v.1, p. 686-737; VALASTRO CANALE, 2000.

45 (ERMOLDO, I, v.97)

46 (ERMOLDO, I, vv.318-319)

47 Para el significado de "los hijos de Sara" "moros", "sarracenos" consultar ISIDORO DE SEVILLA, Etimologías, IX, 2, 57, vol.1, p.748-750. THEGAN, c.34 utiliza el término "sarraceno". Cf. RODRÍGUEZ, 1997, p. 509/514.

$48 \mathrm{La}$ tradición épica virgiliana se encuentra presente a lo largo de la obra y constituye una característica sobresaliente de la práctica escrituraria no 
solamente de Ermoldo sino del renacimiento carolingio. Cf. In Honorem Hludowici Pii, Elegia Ermoldi, v.1-35, ed. E. FARAL, pp.2-4. Cf. ENCUENTRA ORTEGA, 2005, p.445-455.

49 Ermengarda y Judith representan los dos grandes linajes rivales de la crisis del 829-833. Cf. É MAGNOU-NORTIER, "La tentative..., 1" parte, p.331; LE JAN, 2003.

50 Se refiere a esta ligazón entre poesía e historia como "espacio poético, reflexión política" (p.71-123).

51 NITHARDUS, Histoire des fils de Louis le Pieux, édités et traduites par Philippe LAUER, París, Champion, 1926, 2ª edición 1964, I, Prólogo le dedica en texto a Carlos y le advierte que preste atención en "los tiempos terribles de su piadoso padre", acusado de ser el causante de las divisiones internas, inclusive familiares (I, c.3) y de ser incapaz para gobernar, incapacidad que ve reflejada en la actitud pasive que asume ante los hechos.

\section{REFERÊNCIAS}

Airlie, S. The world, the text and the Carolingian: royal, aristocratic and masculine identities in Nithard's Histories. In: Wormald, P.; Nelson, J. (ed.) Lay Intellectuals in the Carolingian World. Cambridge: Cambridge University Press, 2007.

Althoff, G.; Fried, J.; Geary, P. (ed.) Medieval Concepts of the Past. Ritual, Memory, Historiography. Washington D.C. and Cambridge: German Historical Institute and Cambridge University Press, 2002.

Althoff, G. Die Macht der Rituale: Symbolik und Herrschaft im Mittelalter. Darmstadt: Primus-Verlag, 2003.

Althoff, G. Spielregeln der Politik im Mittelalter: Kommunikation in Frieden und Fehde. Darmstadt: Primus-Verlag, 1997.

Astronomus. Das Leben Kaiser Ludwigs, Tremp, E. (ed.) Hannover, Monumenta Germaniae Historica, Scriptores rerum Germanicarum, in usum scholarum separatim editi, 64 (MGH, SS rer. Germ, in us. schol. 64), 1995.

BARKAÏ, R. Cristianos y musulmanes en la España medieval (El enemigo en el espejo). Madrid: Rialp, 1991, 2ª edición (1ª edición en inglés 1984).

Barkaï, R. (ed.) Chrétiens, musulmans et juifs dans l'Espagne médiévale. De la convergence à l'expulsion París: du Cerf, 1994.

Batany, J. Propagande carolingienne et mythe carolingien: le programme de Louis le Pieux, chez Ermold le Noir et dans le couronnement de Louis. In: BAumgartner, E. (ed.) La Chanson de Geste et le mythe carolingien. Mélanges René Louis. 3 vol. París: Saint-Pére-sous-Vézelay, 1982, vol.1, pp.313-340. 
BeCHer, M. Eid und Herrschaft: Untersuchungen zum Herrscherethos Karls des Grossen. Sigmaringen, Thorbecke, 1993.

BÉDIER, J. Les légendes épiques. Recherche sur la formation des chansons de geste. 4 volúmenes. París: Champion, 1914, 2a ed. corregida y aumentada.

Berkhofer, R. F. Beyond the Great Story: History as Text and Discourse. Cambridge: Harvard University Press, 1997, 2ª edición.

Bouquet, D. (ed.) In Honorem Hludowici. In: Recueil des historiens des Gaules et de la France. París, 1737-1742, VI, pp.1-66 (reimpresión de la edición de Muratori).

Boutelle, D. L. Louis the Pious and Ermoldus Nigellus: an inquiry into the historical reliability of In Honorem Hludowici. Berkeley: University of California, 1970, Tesis Ph.D. en Historia Medieval (en microfilms, Michigan, Ann Arbor, 1971).

Brundage, J. La ley, el sexo y la sociedad cristiana en la Europa medieval. México: FCE, 2000.

Buc, P. The Dangers of Ritual: Between Early Medieval Texts and Social Scientific Theory. Princeton: Princeton University Press, 2001.

Carruthers, M. The Book of Memory: A Study of Memory in Medieval Culture, Cambridge, Cambridge University Press, 1990.

Cirlot, V. (comp.) Epopeya e Historia. Barcelona: Argot, 1985.

Coleman, J. Ancient and Medieval Memories. Studies in the reconstruction of the past. Cambridge: Cambridge University Press; 1992.

Corbellari, A. Joseph Bédier: écriain et philologue, París, Droz, 1998.

Cormier, R. The Problem of Anachrornism: Recent Scholarship on the Frenche Medieval Romances of Antiquity. In: Philological Quarterly, n.53, Iowa, 1974, pp.145-157.

Corradini, R.; Meens, R.; Pössel, C.; Shaw, P. (Hg.) Texts and Identities in the Early Middle Ages. Viena: Austrian Academy of Sciences Press, 2006.

COUMERT, M. Origines des peuples: les récits du Haut Moyen Âge occidental (550850). París: Institut d'études augustiennes, 2007.

Davis, J.; McCormick, M. (ed.) The Long Morning of Medieval Europe. New Directions in Early Medieval Studies. Hampshiere: Ashgate, 2008.

Davies, W.; Fouracre, P. (ed.) The Settlement of Disputes in Early Medieval Europe. Cambridge: Cambridge University Press, 1986.

Depreux, Ph.; Esders, S. (coord.). ANR-DFG HLUDOWICUS La productivité d'une crise: Le règne de Louis le Pieux (814-840) et la transformation de l'Empire carolingien. Proyecto de investigación común entre la Universidad de Limoges y la Universidad Libre de Berlín, 2008-2011, cf. http://www.hludowicus.eu. 
Depreux, Ph. Les Sociétés occidentales du milieu du Vie. à la fin du IXe. Siècle. Rennes: Presses Universitaires de Rennes, 2002.

Depreux, Ph. Prosopographie de l'entourage de Louis le Pieux (781-840). Sigmaringen: Thorbecke, 1997.

Ducketr, E. Carolingian Portraits: A Study in the Ninth Century. Michigan: Ann Arbor, 1962.

Duggan, J. Medieval Epic as Popular Historiography: Appropriation of Historical Knowledge in the Vernacular Epica. In: Grudriss der Romanischen Literaturen des Mittelalters. Vol. 11: La Líttérature historiographique des origines à 1500, 1: Partie historique, ed. Hans Ulrich Gumbrecht, Ursula Link-Heer y Peter-Michael SpAngenberg, Heidelberg, Carl Winter Universitätsverlag, 1986, pp.285-311.

Dümmler, E. (ed.) In Honorem Hludowici. In: MGH. Poet. Lat., II, Berlín, 1881.

Ermoldus Nigellus. Poème sur Louis Le Pieux, et Épittres au Roi Pépin. édités et traduites par Edmond FARAL. París: Champion, 1964, 2 ${ }^{\text {a }}$ edición (1 ${ }^{\mathrm{a}}$ ed. 1932).

FALKowski, W.; SAssier, Y. (eds.) Le monde carolingien: bilan, perspectives, champs de recherches. Actes du colloque international de Poitiers, Centre d'Études supérieures de Civilisation médiévale, 18-20 novembre 2004, Turnhout, Brepols, 2009.

Fentress, J.; Wickham, C. Social Memory. Oxford: Blackwell, 1992.

Fichtenau, H. Living in the Tenth Century: Mentalities and Social Orders. Chicago: University of Chicago Press, 1991.

Fleiner, C. D. In Honor of Louis the Pious, a Verse Biography by Ermoldus Nigellus (826): An Annotated Translation. Virginia: University of Virginia, 1996. Tesis Ph.D. en Historia Medieval (en microfilms, Michigan, Ann Arbor, 1996).

Flori, J. La caricature de l'Islam dans l'Occident médiéval. Origine et signification de quelques stéréotypes concernant l'Islam. In: Aevum 66-2, Milán, 1992, pp.245-256.

FrAppier, J. Peinture de la vie et des héros antiques dans la littérature française du XIIe et du XIIIe siècle. In: FrApPIER, J. Histoire, mythes et symboles: études de littérature française. Génova: Publications Romanes et Française 137, 1976.

Frappier, J. Chrétien de Troyes. Sa vie et son oeuvre, París, Hatier, 1957.

Fustel De Coulanges, N. Histoire des institutions politiques de l'ancienne France. 6 vols. París: Hachette, 1908. El inicio de la obra data de 1870.

Ganshof, F-L. The Carolingians and the Frankish Monarchy: Studies in Carolingian History. Nueva York: Cornell University Press, 1971.

Ganshof, F-L. Frankish Institutions under Charlemagne. Providence: Brown University Press, 1968.

Ganshof, F-L. Louis the Pious Reconsidered. In: History, 42, 1957, pp.171-180. 
Garipzanov, I. The Symbolic Language of Authority in the Carolingian World (c.751877). Leiden: Brill, 2008.

Gazeau, V.; Bauduin, P.; Modéran, Y. (dir.) Identité et Ethnicité. Concepts, débats historiographiques, exemples (IIIe-XIIe siècle). París: Publications du CRAHM No3, 2008.

Geary, P. Phantoms of Remembrance. Memory and Oblivion at the End of the First Millennium. New Jersey: Princeton University Press, 1994.

Gilson, E. Héloise et Abélard: études sur le Moye Âge et l'Humanisme. París: Vrin, 1938.

Godman, P. Poets and Emperors. Frankish Politics and Carolingian Poetry. Oxford: Clarendon Press, 1987.

Goetz, H-W. (ed.) Die Aktualität des Mittelalters. Bochum: Wincler, 2000.

Goffart, W. The Narrators of Barbarian History (A.D. 550-800). Jordanes, Gregory of Tours, Bede, and Paul the Deacon. $2^{\text {a }}$ edición. Indiana: University of Notre Dame Press, 2005. (1 $1^{\text {a }}$ edición 1988).

Guglielmi, N. Sobre historia de las mentalidades e imaginario. Buenos Aires: PRIMED/CONICET, 1991.

HeIdecker, K. (ed.) Charters and the Uses or the Written Word in Medieval Society. Turnhout: Brepols, 2000.

Hernández, A. Los límites de los conceptos "agustinismo político" y "gelasianismo" para el estudio de las ideas acerca del poder y la sociedad en la Alta Edad Media. Revista Signum, vol. 11, n.1, 2010, p.26-48.

Houts, E. (ed.) Medieval Memories: men, women and their past, 700-1300. Londres: Longman, 2001.

Hummer, H. Politics and Power in Early Medieval Europe. Alsace and the Frankish Realm, 600-1000. Cambridge: Cambridge University Press, 2006.

InNEs, M. State and Society in the Early Middle Ages: The Middle Rhine Valley, 4001000. Cambridge: Cambridge University Press, 2000.

Iogna-Prat, D. La Maison Dieu. Une histoire monumentale de l'Eglise au Moyen Âge. París: Seuil, 2006.

Isidoro De Sevilla. Etimologías. ed. bilingüe preparada por José Oroz Reta y Manuel Marcos Casquero, introducción general Manuel Díaz Y Díaz, 2 volúmenes, Madrid, Biblioteca de Autores Cristianos, 1993, $2^{\text {a }}$ ediciónJONG, M. The Penitential State. Authority and Atonement in the Age of Louis the Pious - 814-840. Cambridge: Cambridge University Press, 2009.

Jong, M.; Theuws, F.; Van Rhijn, C. (ed.) Topographies of Power in the Early Middle Ages. Leiden: Brill, 2001. 
Jong, M. Power and humility in Carolingian society: the public penance of Louis the Pious. In: Early Medieval Europe. v. 1, n.1, 1992, pp.29-52.

Kantorowicz, E. Laudes Regiae: A Study in Liturgical Acclamations and Medieval Ruler Worship. Berkeley and Los Angeles: University of California Press, 1946.

Kantorowicz, E. The King's Two Bodies: A Study in Medieval Political Theology. New Jersey: Princeton University Press, 1957.

LE JAN, R. (dir.) L'historiographie des élites dans le haut Moyen Age. Actes de colloque, Universités Marne-la-Vallée et Paris 1, 27 et 28 novembre 2003.

LE JAN, R. (ed.) La Royauté et les elites dans l'Europe carolingienne (du début du VIIIe siècle aux environs du 920). Lille: Centre d'Histoire de l'Europe du Nord-Ouest, 1998.

LEJEUnE, R. Recherche sur le teme: le chanson de geste et l' histoire, Lieja, Bibliothèque de la Faculté de Philosophie et Lettres de l'Université de Liège, 1948.

Lejeune, R. L'oeuvre de Jean Renart. Contribution à l'étude du genre romanesque au moyen-âge. París: Droz, 1935; LOT, F. Joseph Bédier (1864-1938). París: Droz, 1939.

Lot, F. Études sur les légendes épiques française. París: Champion, 1958.

Lutz-Bachmann, M.; Fidora, A. (hrsg.) Juden, Christen und Muslime. Religionsdialoge im Mittelalter, Darmstadt, Wissenschaftliche Buchgesellschaft, 2004.

Maitland, F. Domesday Book and Beyond: Three Essays in the Early History of England. Cambridge: Cambridge Universty Press, 1907.

Magnou-Nortier, E. La tentative de subversion de l'État sous Louis le Pieux et l'œuvre des falsificateurs. 2 partes. In: Moyen Âge: Revue d'histoire et de philologie, v.105, n.2 y n.3-4, 1999 , pp.331-365 y pp.615-642.

Maitland, F.; Pollock, F. The History of English Law before the Time of Edward I. 2 vols. 2.ed. Cambridge: Cambridge Universty Press, 1911.

Martínez Pizarro, J. A Rhetoric of the Scene: Dramatic Narrative in the Early Middle Ages. Toronto: University of Toronto Press, 1989.

Mcсовміск, M. Eternal Victory: Triumphal Rulership in Late Antiquity, Byzantium, and the Early Medieval West. Cambridge: Cambridge Univerity Press, 1990.

Mcкitterick, R. Charlemagne: The Formation of a European Identity. Cambridge: Cambridge University Press, 2008.

Mckitterick, R. Perceptions of the Past of the Early Middle Ages. Notre Dame: University of Notre Dame Press, 2006.

Mckitterick, R. History and Memory in the Carolingian World. Cambridge: Cambridge University Press, 2004.

Mckitterick, R. The Illusion of Royal Power in the Carolingian Royal Annals. In: English Historical Review 460, 2000, p.1-20. 
Mckitterick, R. Political ideology in Carolingian historiography. In: Hen, Y.; Innes, M. (ed.) The Uses of the Past in the Early Middle Ages. Cambridge: Cambrigne University Press, 2000.

Mckitterick, R. (ed.) The New Cambridge Medieval History. Vol. II: c.700-c.900. Cambridge: Cambridge University Press, 1990.

MCкitterick, R. (ed.) The Uses of Literacy in Early Medieval Europe. Cambridge: Cambridge University Press, 1990.

MскіттеRICк, R. The Carolingian and the Written World. Cambridge: Cambridge University Press, 1989.

MCкItTerick, R. The Frankish Kingdoms Under the Carolingians, 751-987. Londres: Logman, 1983.

Menéndez Pidal, R.; Catalán, D.; Bustos, M. M. La Épica medieval española: desde sus orígenes hasta su disolución en el romancero, Madrid, Espasa-Calpe, 1992.

Menéndez PìdAL, R. Romancero hispánico (hispano-portugués, americano, sefardí). Teoría e historia. Madrid: Espasa-Calpe, 1953.

Minois, G. Charlemagne. París: Perrin, 2010.

Montaner, A "Prólogo". In: Cantar del Mio Cid. Edición, prólogo y nota de A. Montaner. Estudio preliminar de F. Rico. Barcelona: Crítica, 1993, 2ª ed.

Mora-Lebrun, F. Comment jouer avec les auctores. Sur quelques récritures carolingiennes de Virgile (Ermold, Abbon, le Waltharius). In: Boutet, D.; EsmeinMora-Lebrun, F. L'Enéide médiévale et la chanson de geste. París: Honoré Champion, 1994.

Morrisey, R. L'Empereur à la barbe fleurie. Charlemagne dans la mythologie et l'histoire de France. París: Gallimard, 1997.

Morsel, J. Les sources son-elles 'le pain de l'historien'? In: Hypothèses 2003. Travaux de l'École doctorale d'histoire de l'Université Paris I Panhéon-Sorbonne. París: Publications de la Sorbonne, 2004.

Muratori, L. (ed.) In Honorem Hludowici. In: Scriptores rerum italicarum, II, $2^{\text {a }}$ edición, $380 f f$.

Nelson, J. Charlemagne and the Paradoxes of Power: The Reuter Lecture 2005, Southampton, University of Siuthampton, 2006.

Nelson, J. Charlemagne and Empire. In: Davis, J.; McCormick, M. (ed.) The Long Morning of Medieval Europe. New Directions in Early Medieval Studies. Hampshiere: Ashgate, 2008.

Nelson, J. Gender and genre in women historians of the Early Middle Ages. In: Janet Nelson. The Frankish Wolrd, 750-900. Londres: Hambledon Press, 1996. 
Nelson, J. Kingship and empire in the Carolingian world. In: MCKitTerick, R. (ed.) Carolingian Culture: emulation and innovation. Cambridge: Cambridge University Press, 1994.

Nithardus. Histoire des fils de Louis le Pieux, édités et traduites par Philippe Lauer. París: Champion, 1926, 2a edición 1964.

Noble, T. Images, Iconoclasm, and the Carolingias. Filadelfia: University of Pennsylvania Press, 2009.

Noble, Th. Charlemagne and Louis the Pious. Lives by Einhard, Notker, Ermoldus, Thegan, and the Astronomer, Translated with Introductions and Annotations by..., Pennsylvania, The Pennsylvania State University, 2009.

Noble, Th. Louis the Pious and his Piety Reconsidered. In: Revue belge de philologie et d'histoire 58, 1980, pp.297-316.

Noble, Th. The Monastic Ideal as a Model for Empire: The Case of Louis the Pious. In: Revue Bénédictine vol. 86, №3-4, 1976, pp.235-250.

NoBle, Th. Secular sanctity: forging an ethos for the Carolingian nobility. Wormald, P.; Nelson, J. (ed.) Lay Intellectuals in the Carolingian World. Cambridge: Cambridge University Press, 2007.

Perrin, C. Un historien français: Ferdinand Lot (1866-1952). París: Droz, 1968.

Poly, J-P. Le chemin des amours barbares: genèse médiévale de la sexualité européenne. París: Perrin, 2003.

Raby, F. A History of Secular Latin Poetry in the Middle Ages, 2 v. Oxford: The Clarendeon Press, 1957, $2^{\text {a }}$ edición (1ª edición 1934).

RAU, R. (ed.) Quellen zur karolingischen Reichsgeschichte I: Die Reichsannalen. Einhard, Leben Karls des Grossen, zwei "Leben" Ludwigs, Nithard Geschichten. II: Jahrbücher von St. Bertin, Jahrbücher von St. Vaast, Xantener Jahrbücher. III: Jahrbücher von Fulda, Regino Chronik, Notker, Taten Karls, Darmstadt, Wissenschaftliche Buchgesellschaft, 1968-1969.

RHijn, C. van. Shepherds of the Lord. Priests and Episcopal Statutes in the Carolingian Period. Turnhout: Brepols, 2007.

Rochwert-Zuili, P. Du poème a l'histoire. La geste cidienne dans l'historiographie alphonsine et neo alphonsine (XIIIéme-XIVéme siècles). Tese defendida en 1998 en la Université Paris XIII.

Rodríguez De La Peña, M. A. Los Reyes Sabios. Cultura y poder en la Antigüedad Tardía y la Alta Edad Media. Madrid: Actas, 2008.

Rodríguez, G. La invención del pasado: memoria, mito e historia en Ermoldo Nigello. In: Rodríguez, G. (comp.) Textos y contextos. Exégesis y hermenéutica de obras medievales (siglos IV-XIII). Mar del Plata: Eudem, 2009. 
Rodríguez, G. La construcción histórica de la imagen del otro en las narrativas carolingias de la novena centuria. In: RodríGuez, G. (dir.) Historia, Literatura y Sociedad: aproximaciones al mundo medieval desde el siglo XXI. Mar del Plata / Bahía Blanca: Cultura Fusión / CEICAM, 2011 (en prensa).

Rodríguez, G. Mito e historia en Astrónomo y Thegan. In: Cattedra, O. (dir.) Mito e Historia: el umbral del tiempo. Mar del Plata: Suárez, 2011(en prensa).

Rodríguez, G. La historia política de la Alta Edad Media y los historiadores carolingios de la novena centuria: los nuevos rumbos historiográficos. In: RodRíGuEZ, G. (dir.). Textos y contextos (II). Exégesis y hermenéutica de obras tardoantiguas y medievales. Mar del Plata: Eudem, 2011 (en prensa).

Rodríguez, G. Vade retro, Satanás. Imágenes medievales del Islam. In: Actas del IV Congreso Argentino de Hispanistas, Mar del Plata, Asociación Argentina de Hispanistas y Facultad de Humanidades de la Universidad Nacional de Mar del Plata, 1997.

SAID, E. Orientalismo. Madrid: Libertarias, 1990.

SARrazin, C. (dirs.) Palimpsestes épiques. Récritures et interférences génériques. París: Université Paris-Sorbonne, 2006, p.85-97.

Schramm, P. E. Die deutschen Kaiser und Könige in Bilden ihrer Zeit - 751-1190. 2ed. Munich: Prestel, 1983 (1ª edición 1928).

Semmler, J. Renovatio Regni Francorum. Die Herrschaft Ludwigs des Frommen im Frankenreich, 814-829/830. In: Godman, P.; Collins, R. (ed.) Charlemagne's Heir. New Perspectives on the Reign of Louis the Pious (814-840). Oxford: Clarendon Press, 1990.

Schmitт, J-C. Le Temps 'Impensé' de l'histoire ou double objet de l'historien? In: Cahiers de Civilisation Médiévale, n. 48, Poitiers, 2005, pp.31-52.

SÉNAC, Ph. Le monde carolingien et l'Islam: contribution à létude des relations diplomatiques pendant le Haut Moyen Âge (VIII-X siécle). París: L’Harmattan, 2006.

SÉnAC, Ph. Les Carolingiens et al-Andalus (VIIIe-IXe siècles). París: Maisonneuve et Larose, 2002.

SÉnAC, Ph. L'image de l'autre. Histoire de l'Occident médiévale face à l'Islam. París: Flammarion, 1983.

Smith, J. Europe after Rome. A new cultural history, 500-1000. Oxford: Oxford University Press, 2005.

Spiegel, G. The Past as Text. The Theory and Practice of Medieval Historiography. Baltimore, 1999.

Spiegel, G. Romancing the Past. The Rise of Vernacular Prose Historiography in Thirteenth-Century France. Berkeley: University of California Press, 1993. 
Sтоск, B. History, Literature, Textuality. In: Sтоск, B. Listening for the Text: on the uses of the past. Filadelfia: University of Pennsylvania Press, 1996.

Story, J. (ed.) Charlemagne: Empire and Society. Manchester: Manchester University, 2005.

Sypeck, J. Becoming Charlemagne: Europe, Baghdad, and The Empires of A.D. 800. Nueva York: Ecco / Harper Collins, 2006.

Tenberken, W. Die Vita Hludowici Pii auctore Astronomo: Einleitung und Edition, Rottweill, 1982.

Thegan, Die Taten Kaiser Ludwigs, Ernst Tremp (ed.), Hannover, Monumenta Germaniae Historica, Scriptores rerum Germanicarum, in usum scholarum separatim editi, 64 (MGH, SS rer. Germ, in us. schol. 64), 1995

Tolan, J. Les Sarrasins. L'Islam dans l'imagination européene au Moyen Âge. París: Aubier, 2003.

Tolan, J. (ed.) Medieval Christian Perceptions of Islam: a Book of Essays. Nueva York: Garland, 1996.

Tourneur-Aumont, J. Pouvoir central et régionalisme au temps de Louis le Débonnaire: la politique d'Ermold le Noir (826) et d'Ermeno de Poitiers (838). In: Bulletin Société des Antiquaires de l'Ouest, ser. 3, 6, Poitiers, 4º trimestre de 1923, pp.449-475.

Treffort, C. Mémoires carolingiennes. L’epitaphe entre célébration mémorielle, genre littéraire et manifeste politique (milieu VIIIe. - début XIe. Siècle). Rennes: Presses Universitaires de Rennes, 2007.

Tremp. Thegan und Astronomus, die beiden Geschichtsschreiber Ludwigs des Frommen. In: Godman, P.; Collins, R. (ed.) Charlemagne’s Heir. New Perspectives on the Reign of Louis the Pious (814-840). Oxford: Clarendon Press, 1990.

Tyler, E.; Balzaretti, R. (ed.) Narrative and History in the Early Medieval West. Turnhout: Brepols, 2006.

Valastro Canale. Herejías y sectas en la Iglesia Antigua. El octavo libro de las Etimologías de Isidoro de Sevilla y sus fuentes. Madrid Universidad Pontificia Comillas, 2000.

Waitz, G. Deutsche Verfassungsgeschichte. 9 v. Kiel: Ernst Homann, 1876-1896. El inicio de la obra data de 1844.

Wickнам, C. The inheritance of Rome. A History of Europe from 400 to 1000. Nueva York: Viking, 2009 